\title{
Immigration Push: A New Approach to Agelong Resistance
}

\author{
Ujunwa P. Okeahialam \\ Sacred Heart Church \\ $7154^{\text {th }}$ Street Alamosa, CO. 81101 \\ (719) 821 5534/// pokeahialam@yahoo.com
}

\begin{abstract}
Migration is a universal phenomenon but becomes more problematic when it is trans-national. Though similar reasons may influence both forms of migrations, there are heightened fears among people towards those they consider as non-natives. These fears have always been resisted leading non-natives to either fight their way or beg to be integrated. The idea of resistance fits the perspective of nationalism as a theoretical framework. On the other hand, the various manners of trying to overcome the acts of resistance in most recent times like joining a caravan, wielding a flag, jumping a wall, etc. cannot be called fighting in the true sense neither can they be called begging at the same time. This work using secondary data, considers these approaches as novel and deserving of new responses. In its absence, it amounts to mere elitism demonizing those applying their age long known resistance to confront what they fear.
\end{abstract}

Keywords: Migration, Nationalism, Resistance, Fighting, Begging,

DOI: $10.7176 / \mathrm{PPAR} / 10-3-04$

Publication date:March $31^{\text {st }} 2020$

\section{Introduction}

Immigration, understood as the movement of people from one place to another has been part of humanity aboriginally. The early man was described as a wanderer (Ezea, 2015) and his movement was for reasons of survival. Consequently, he moved in the quest for food, away from inclement weather, or running away for safety. Describing this life Musisi (1981) wrote,

Early man was a wanderer - of necessity rather than choice. Food was scarce and hard to come by. Enemies, on the other hand, were very very many. From the earliest times, however, the conditions which man lives, have been powerfully influenced by the ease and speed with which he has been able to move himself and his materials from point to point on the earth's surface. (p. 60)

Movements can also be for other reasons, as when Abraham moved in response to a divine call for him to leave his native land in Ur of the Chaldeans (Gen. 12, $N A B$ ). Regardless of the reason, people move and will continue to move to the admiration or resistance of others. Considered on its face value, migration is a human and global phenomenon and history proves it to be so. According to Lee (1966), "Migration is defined broadly as a permanent or semi-permanent change of residence" (p. 49). Viewed from this prism, all ambulatory activities and more, support the ubiquitous nature of migration. However, this work goes farther to articulate it more from the perspective of cross-national movements. About this, some have not only considered its phenomenal universality but also acknowledged it as a moral right on the plane of fundamental human rights ${ }^{1}$-although it is not considered an absolute right (Oberman, 2016). This draws from the sense of freedom of movement within a nation-state whereby the same reasons to move internally can inspire the quest to move externally — such as the quest for survival and greener pastures; as well as for job, for worship, for association etc.

Recently, there are indications that people move to overcome the harmful consequences of climate change as those associated with desertification, flooding, and the scarcity of water, which affects agriculture. This was well articulated in that 1990 executive summary of the International Organization for Migration (IOM) which quoted the position of the International Panel on Climate Change (IPCC) that, "The greatest single impact of climate change could be on human migration - with millions of people displaced by shoreline erosion, coastal flooding and agricultural disruption" (p. 9). A July 31, 2019 UN news update attributes that in 2018 alone about 17.2 million have left their homes for some new places due largely to effects of climate change. ${ }^{2}$ What is of note here is that this is not a recent phenomenon, even though the awareness and rhetoric on the effects of climate change seem to be in the news now more than before. For example English (1959) opined that the peopling of the Nigerian ethnic nationalities have migrating influxes from the expansion of the Sahara desert and the drying up of the rivers. These migrants according to him would have pushed the aborigines in the area further South or would have mixed up with them.

In addition, some have levelled the rampant corruption that have exacerbated the incidence of joblessness,

\footnotetext{
${ }^{1}$ Lee, E. S. A Theory of Migration Demography, Vol. 3, No. 1. (1966), p. 47-57

${ }^{2}$ UN News (31July 2019): Climate change (Global Perspective Human Stories) UNICEF/UNI82205/Holt

Men on camels and donkeys travel through a dust storm in the desert near the western city of Mao, in the Kanem Region of Chad.
} 
especially that of the inadequate remuneration for highly skilled workers as another propeller of the migration wagon (Schneider, 2015). Nevertheless, what seems mooted in all these is the fact that no nation has ever folded her arms and watched others take up their place and overwhelm their culture. This is the trust of this work. Therefore, this work opines that the success of the migrant in the foreign land, with regards to the issue of integration, is either to fight or to beg-fight to win or beg to be accepted.

However, using the typical framework of nationalism this work reveals the fact that immigration as the movement from one place to another; whether to take up permanent residence in the new place or just to explore it for any future benefits, is not always embraced by all with open arms. In its submission, this work recognizes that wherever migration has succeeded, the people either had fought their way or had begged to be accommodated. Therefore, evidence of some recent waves of immigration today that is neither fully fighting nor fully begging demands a novel approach without demonizing those resisting it as they still struggle with the age old fear of what can happen to their place, language, and culture with the melting of the new immigrants into their space.

\section{Theoretical Framework: Nationalism}

The possible misunderstanding of using nationalism as the theoretical framework here hinges on its widespread use and understanding in relation to politics and independent movements. However, throughout history the concept also applied in the area of contending ideologies where loyalty was sought for in the service of the larger interest of most people. An example of this is the concept of British nationalism that was linked in the anti-monarchial spring of the $17^{\text {th }}$ century (Calhoun, 1993). Likewise, in the $18^{\text {th }}$ century French nationalism sprung around the concepts of "Liberty, Equality, and Fraternity (Duncan, 1934).

However, when commonly applied, Nationalism is the identification with one's own nation and support for its interests as against the imposition of a foreign interest. This according to Calhoun (1993) spills from a recognition of division among peoples into nations with marked characteristics and who are at best, self-ruling. This was greatly displayed in the nationalist movements of the $20^{\text {th }}$ century in colonized lands as in Africa and Asia - with whom the crème of nationalism was the realization of political independence. Consequently, one thing clear about nationalism is the sense of dissatisfaction felt by people who think about the actions of elites among them or presence of the other in their midst that tend to rob them of their presumed rightful place in their place (Fukuyama, 2006). This threat can be real in the sense that the non-native has started to exhibit power, or it can be imagined in the sense that these non-natives can overwhelm the natives in a series of ways, either cultural, language, economic, politics, religion, etc.

In the literature classic Things Fall Apart, Achebe (1994) showed the sense of fear the Igbos had on the openness of some of her people to the Whiteman because of how it will dilute the culture and religion of the people. In the same way, the resistance of people like King Jaja of Opobo to the White traders was purely about their economic takeover of trading activities in the area more than religion or cultural (Chinweizu, 1987). From the biblical account of the exodus, although the fear of the Jewish community expressed by Pharaoh to which he directed the death of the male sons hinged on the possible escape from serving them-yet the fear of the peoples' growing numerical strength and influence in a foreign land could not be discounted. In the same vein, many literatures that highlight anti-immigrant reasons point to things including diminishing wages, growing crimes, and suffocating of social services (Brader, et al. 2008; Burns, \& Gimpel, 2000) that the new comers are heavily contributing to. In response to these scenarios, something common from the presumed natives is that, one way or the other, they have tried to resist what they feared as the takeover of their place, culture, language, etc. by the new immigrants - even when they misunderstand the stranger who is only seeking a right to pass over to a new place.

In the Bible, for example Sihon king of the Amorites resisted Israel passing through their land leading to the eventual confrontation (Numbers 21: 21ff). It was also to maintain the integrity and purity of their country that Balak the Moabite, pleaded with the diviner Balaam to curse the Jews so to make it easier for him to defeat and drive them out of his territory (Numbers 22). Same thing happened in the cause of Islam when some in Medina became uncomfortable with the rising profile of Mohammed and his fellow immigrants'. According to (Guillaume, 1956) the resistance shown by some leading Medinans arose out of the feeling that they had "given up more than they had gained" (p. 41).

A Nigerian musician, Sonny Okosun once sang about this urge to resist outsider incursion in the album "Papa's Land." Therein, and in an effort to raise African consciousness to the plight of Africans in the Southern region of the continent who were under different forms of apartheid he raised the question, "We want to know who owns the land." This sense of national consciousness is not far from the mind of another musician Oliver de Coque, who summarized that there are those who own the land because a place does not hang together like vegetables. This is the battle or quest all nationalist struggles aim to address so as to reclaim control of the place they claim to be theirs against those they claim to be strangers.

\section{Incidence of Resistance through History}

It will be presumptuous to claim to enumerate all incidences of immigration resistance or success throughout 
history. However, a few will be presented here as evidence that people do not fold their arms watching as their land, culture, etc. are overwhelmed by others. In biblical times for instance, migrating Jews were resisted by Egypt who felt threatened with the growing Jewish population and made efforts to curb the growth through decreeing the killing of all male children born (Ex. 1: 15-16). They were resisted by a coalition of West Jordanian kings who feared their military powers in defeating other nations (Josh. 9: 2); as well as the Northern Palestinian kings (Josh. 11). They were also resisted the right to passage through the Edomite territory while on their pilgrimage to the Promise Land (Nm. 20). Even their promise to pay for every food and water they will need during their passage was vehemently refused by Sihon king of Heshbon who also went ahead to mobilize a force against them (Deut. 2: 26ff). All these happened even though they were not intending to settle among these people.

The battles fought by Mohammed and his earliest followers in the wake of their spread throughout the Arabian peninsula were aimed at subduing the resistance posed to their efforts to fuse the peoples into one Ummah-for which he was open to some forms of enculturation. One of such incident as narrated by Aslan (2011) though with some caveat - and as happened in Medina — stated that,

Supposedly, to facilitate the Jews' acceptance of his prophetic identity, Muhammad connected his community to theirs by adopting a number of Jewish ritual practices. To his surprise, however, the Jews not only rejected him but also strenuously argued against the authenticity of the Quran as divine revelation. Worried that the rejection of the Jews would somehow discredit his prophetic claims, Muhammad had no choice but to turn violently against them. (p. 97)

In the American history, the Native Americans resisted the Spaniards who were trying to gain foothold in their land. One only need to read the Devastation of the Indies ${ }^{1}$ to learn about the gruesome takeover of the land of the natives. Their approach in this takeover was aptly described as those of "Ravening wild beasts, wolves, tigers, or lions that had been starved for many days" (p. 29). It noted that these happened because the people, one way or the other, resisted the force to serve the Spanish majesty. One of such resistors Hatuey, in the present day Cuba, was being lured to the Christian faith of the Spaniards as a way of saving himself; and when told upon inquiry that the Spaniard Christians also go to heaven, he retorted that he would prefer hell instead.

The wave of resisting immigrants and the immigrants fighting their way through did not end with the above rein of Spanish terror. In the early $17^{\text {th }}$ century the members of the Virginia Company of London who eventually settled in Jamestown were equally attacked by the Native Americans until one of their leaders, Smith, undertook a more diplomatic approach of befriending the natives. ${ }^{2}$ Equally, the clarion "Remember the Alamo" and the counter force that gave birth to the state of Texas as part of the USA in 1835, cannot be told without the resisting force of Mexico to quell the recalcitrance brought into the area by the migrants who were, initially tolerated in the San Antonio area of the then country of Mexico. ${ }^{3}$ Although the migration of Europeans into the New World, all this while, continued carte blanche, it was known that older migrants were not always excited with the arrival of newer ones. Lieberson (1996) spoke about this attitude as American dubiousness about new migrants and their concern about the ability of the new comers to be well integrated into American way of life and citizenship. The resistance equally took religious coloration where according to Connor (2017), the new colonies had laws "that either discriminated against Catholics or forbade them from entering their borders altogether" (p. ix- $x$ ).

The lands of ancient Africa had its own share of resistance. One of such resistance was that posed against the Arabic influx into North Africa. Although Naude (1978) noted how Byzantine stranglehold made the Northern Africans welcoming to the Muslim expansionists, yet it was evident that the incursions was not that of laying the red carpet. Ringmar (2016), noted that the Berbers of North Africa resisted and that they were not rightly defeated militarily. The contention was that their leadership were, in a way, bought over. In addition, stories of resistance to apartheid system in Southern Africa contributed to the making of that rainbow nation of today (Pillay 2004). Noting when the resistance started Motlhabi, M. (1987) wrote that, "In fact, resistance to white domination in South Africa began right from the start of colonialism when the Khoi people in the Western Cape abandoned trade with Dutch traders as soon as they realized that the latter intended to settle and demand land for their use" (p. 34). Even in recent times the blacks of that country engaged in xenophobic attacks of Africans of other nationalities who immigrated into their country - they wanted them to leave and to accomplish this their resisting efforts witnessed great flow of blood.

Examining what happened in the era of the Roman Empire, one could speak of the wars and their resistance as those directed by the ambitions of personalities who wanted to wield power. This assertion is supported by Souza (2008) in these words describing the time that, "Social bonds structured war-making. Group of warriors clustered around prominent leaders" (p. 139). However, the same thing cannot be fully said of what history regarded as the barbarian invasion that could be said to be unsuccessfully resisted. According to Goffart (1981), these were the neighbors who inhabit the different frontiers of the empire, not a collectivity of marching forces, but who had been kept at bay with Roman military might; and whose success was made possible by some internal

\footnotetext{
${ }^{1}$ De Las Casas, B. (1992). The devastation of the Indies. Translated by Herma Briffault. (Baltimore: The John Hopkins University Press

${ }^{2}$ Wiegand, S. (2014). U.S. History for dummies (Hoboken, NJ: John Woley \& Sons)

3 ibid
} 
problems in the empire. Their success, which brought about a new immigratory configuration, did not happen without Roman resistance.

The story of Attila of Huns equally shows the mobilization and integration of a people as distinct from the others, thereby holding their own than being always eroded in the endless flux of wars and restiveness by migrating forces (Roberts, 1987). This shows, like in other instances, the one thing constant, which is the resistance of others for any reason, the summary of which is the unwilling to share in the citizenship of the place with new migrants.

At the risk of threading into a controversial territory, it can be said that the coalition of Arabs who marshalled their forces against the Jews in the endless Palestinian-Jewish skirmishes did so with the intention of saving the purity of the land against the Jews. According to Morris (2008), it was part of a campaign to restore the place to their true owners. It was also fought with the intension of preserving the Arab cultural pride, which in the calculation of those amalgamated forces does not include the state of Israel - a people they claimed were products of UN creation (Mohammad, 2017). Therefore, it is undisputed that both the 1948 and the 1967 wars against Israel were acts of resistance against a people, they claim, who have migrated into a place depicted as foreign to them.

These are not the only instances of resistance that had happened throughout history. However, these are shown as evidences that, like migration itself, resistance to migration is a universal phenomenon and had existed at every epoch of human history and among the different peoples of the world.

\section{Present Realities and Misconceptions}

Apart from ancient Jewish migration that began on a divine order to set apart a people for his own inheritance, migrations have always been associated with these same circumstances: escape from violence, search for survival, search for freedom, greener pastures, joblessness, and because of climate change. As always, there are resisting actions towards newer migrants based on some negative influences their presence is presumed to bring; such as loss of job, threat to public order, adversity to existing welfare systems in the general community as well as towards minority and legal migrant groups, etc. (Fryberg et al, 2011). To this, migrants have either fought their way or pleaded to be accepted. By pleading here is meant the manner of following laid out protocols dictated by the natives for the new comers to reach in order to be accepted and accommodated - even when it is by way of exploiting loopholes in the system to their advantage. What is important in any of these is that there are not noted acts of confrontation or anything considered as an affront against the natives by the migrants.

In the recent times, many European countries have seen increase in the wave of Arab and other African migrants, by land and by sea - most especially since the Arab Spring revolts. The USA has also witnessed growing numbers of migrants from Mexico and many other Central American countries - as depicted in the "caravan" match that eventually became an electoral issue in 2018 midterm elections. Some of these people, it is said, are running away from the harsh realities in their native countries and are drawn to move to places where they think that they will have better futures. In all these circumstances, there are chains of resistance against these migrants, regardless of how small or subtle those may be. In the United States, for instance, there are calls for Comprehensive Immigration Reforms, ${ }^{1}$ which may mean different things for different folks. There are also the apparent harsh rhetoric against migrants ending with the chorus of "Build the Wall.

Against this background, there are those who loquaciously demonize these acts of resistance based on their political and ideological leanings. A study, which considered the influence of media framing of the Arizona SB 1070, discovered a greater support of the Bill in Conservative media more than Liberal media, and a greater support of it from local media (based in Arizona) more than national media (Fryberg, et. al, 2011). Is it a case of who wears the shoe knowing where it pinches or a case that liberals are more receptive of migrants, is an open debate? Regardless of what can be read of it, Hawley (2011), found "demographic context influence" in conservative (Republican) overall attitude towards migrants - meaning that Conservative attitudes towards migrants is not the same everywhere. But suffice it to say that, there is the perception that Liberals are more well accepting of migrants than Conservatives. This may be part of the thinking that the more migrants accepted into the country will quicken the demise of the Republican party and her prospects since more migrants vote for the Democratic party (Gimpel,2010). Therefore, it can be presumed that the Liberal and Democratic leaning to migrants is motivated among other things to the interest of expanding their voting bloc than for any altruism.

From the perspective of religion, one notices variations equally with regards to the issue of migration in the USA. According to McDaniel et al (2011), Evangelicals are less accepting of relaxed immigration rules than mainline Protestants and Catholics. Those against, tend to rationalize on the need for order and the preservation of America's Christian culture. On the other hand, those with a more lenient disposition appeal to issues of Social Justice and the need to be compassionate to those escaping extreme difficulties in their homelands.

\footnotetext{
${ }^{1}$ Most politicians claim that the Immigration system of the USA is broken and need to be reformed. What the reform should include remains contentious. However, for many a Comprehensive plan will include a "Pathway to Citizenship" to illegal migrants; others feel it is rewarding illegality and unfair to those who played by the rules and are waiting in line for their status to be regularized.

${ }^{2}$ A popular chorus at President Trump's "Political Rallies" as a measure of keeping illegal immigrants out especially those coming from the Southern Border.
} 
Without endorsing any of the above ideological or political considerations, this work opines that the natural tendency to resist should not be ignored or demonized. It is inherent in people regardless of culture and time, political leaning or religion persuasion. And because of the context influence in the issue of migration as noted by Hawley (2011), a new approach should be evolved in the immigration debate. This is because it is not quite distinct if the migrants are fighting to have their way or begging to be accepted. For instance, a migrant wielding the flag of his or her home (emigrating) country cannot be said to be begging, yet the flag is not an instrument of war in the ordinary sense of it. A migrant climbing the fence cannot be said to be begging but cannot be accused of fighting. A migrant rehearsing and telling lies to immigration courts cannot be said to be begging, and cannot be accused of fighting. A migrant who fails to honor his court hearing cannot be said to be begging as much as he was not fighting.

On the other side of the issue are the immigration advocates who support and facilitate the movement of the migrants. From their actions, they cannot be said to be begging and they are not fighting, in the real sense of the term itself. The immigration attorney who is coaching the migrant on how to beat the system cannot be said to be begging or fighting for the migrant. The Judges who block executive orders they consider unconstitutional and anti-immigrant cannot be said to be fighting, neither are they begging for them. Social crusaders who denigrate the conditions at the immigration hold centers and what is called family separation cannot be accused of fighting neither are they begging. Moreover, all the media attention to whatever is called inhumanity towards migrants may not be called a bullet or spear attack on those trying to maintain the integrity of their place and culture against new arrivals. Yet, it is not an advocacy on their behalf and pleading that they be accommodated. Therefore, viewed from another lens, what is lacking in these recent moves is that the people are neither fighting nor begging. Rather using the apparatus provided by modernity, they want to make it a duty born of humanity to have the border-doors open without limit. This, in the judgment of this work is where the problem lies because it presumes so much from a humanity that is not wired that way. You either fight your way or you beg-and there is no guarantee that you will win when you fight or that your plea will be listened to because you beg.

On the other hand, it is easier to see how the natives consider anything that is not an explicit plea to be accommodated as confrontational. They are more like fighting in a new way without fighting in the old-fashioned manner with the use of bullets and spears. When migrants boldly defy rules and join caravans and expect the borders to be open, is it anything different from mustering for battle? When migrants wave the flags of their home countries in another country do they look like people begging to be admitted, or is it not a subtle way of saying we have overrun your country-which is a sign of war? When politicians and groups accuse their government's apparent abuse of the rights of migrants without saying something about a migrant who failed to follow the protocol of begging, are they not tying the hands of their nationals from fighting those who have invaded them? What all these show is that, the path of migration has changed and so response to it has to change as well. The marches, the caravans, the flag wielding and waving assemblies can all be considered as banging on the door by uninvited guests, which can only sharpen the urge to resist. One who feels threatened by bangs on the door will not speedily open it but will tend to make the barrier stronger from the inside. The one may call for help from law enforcement and device ingenious ways of repelling the intruder - even to the extent of using violence.

\section{Conclusion}

This work began with the presumption that migration is universal phenomenon and that resistance to the issue of people coming into a new area have always existed. However, looking at the incidences of history it rationalized that migrants have won the quest of integration by either fighting their way unto victory or pleading to be accommodated by following laid down protocols by the native population without being confrontational. But at the root of this work was the observation that some recent immigration questions cannot be said to be following the agelong ways of fighting or pleading. Regardless of this absence, natives or earlier migrants still feel, rightly or wrongly, the same threat of losing a ground they think they have. Consequently, they have continued to resist. In the meantime, their resistance have been attacked with apparent silence of the consequences of the actions of the migrants. The only thing that can come from this is more chaos.

The above notwithstanding, this work, is in no way endorsing violence as a way of settling the immigration question in a world where people have always moved from place to place and for one reason or the other. Rather, it acknowledges the universality of resistance to migrants into any community throughout history. In making that observation, it identified two means of realizing the integration of the new migrants with natives or earlier settlers as, fighting or begging. But considering the observation that these migrants cannot be said to be fully fighting in the real sense of the word, neither can they be said to be begging; there is then need for new and engaging debate on the subject of immigration as to determine how best to respond to the present phenomenon. And until that is had it appears more an act of elitism to demonize those who are resisting the unregulated incidences of migration because they appear, as is, like a banging on the door by an uninvited guest. 


\section{References}

Achebe, C. (1994). Things fall apart. (New York: Anchor Books)

Agai, J. M. (2014). "Did the ancient Egyptians migrate to ancient Nigeria?" Verbum Eccles. Online 35(1), 1-6

Aslan, R. (2011). No god but god: The origins, evolution, and future if Islam. (New York: Random House)

Brader, T., Valentino, N. A., and Suhay, E. (2008). "What triggers public opposition to immigration? Anxiety, group cues, and immigration threat." American Journal of Political Science, 52(4), 959-978

Brown, O. (2008). "Migration and climate change." IOM Migration Research Series 31.

Burns, P and Gimpel, J. G. (2000). "Economic insecurity, prejudicial stereotypes, and public opinion on immigration policy." Political Science Quarterly, 115(2), 201-225

Calhoun, C. (1993). "Nationalism and ethnicity." Annual Review of Sociology, 19, 211-239

Chinweizu. (1987). The West and the rest of us: White predators, Black slaves, and the African elite. (Lagos, Nigeria: Pero Press).

Connor, C. (2017). Pioneer priests and makeshift altars. (Irondale, Alabama: EWTN Publishing, Inc.)

De Las Casas, B. (1992). The devastation of the Indies. Translated by Herma Briffault. (Baltimore: The John Hopkins University Press)

Duncan, W. G. K. (1934). "Liberty, equality and fraternity in the modern world." Australasian Journal of Psychology and Philosophy, 12(1), 1- 15

English, M. C. (1959). An outline of Nigerian history (Longmans: London).

Ezea, M. U. (2015). "Transforming society through Igbo cultural values: The role of information and communication technology (ICT) in the 21st century." World Educators Forum, 7(1), 1-16.

Fryberg, S. A., Stephens, N. M., Covarrubias, R., Markus, H. R., Carter, E. D., Laiduc, and Salido, A. J. (2011). "How the media frames the immigration debate: The critical role of location and politics." Analyses of Social Issues and Public Policy, 00(0), 1-17

Fukuyama, F. (2006). "Identity, immigration, and liberal democracy." Journal of

Democracy, 17(2), 5-20

Gimpel, J. (2010). "Immigration, political realignment, and the demise of Republican political prospects." (Washington, DC: Center for Immigration Studies).

Goffart, W. (1981). "Rome, Constantinople, and the Barbarians." The American Historical Review, 86(2), 275 306

Guillaume, A. (1956). Islam. (Baltimore: Penguin Books)

Hawley, G. (2011). "Political threat and immigration: Party identification, demographic context, and immigration policy preferences.” Social Science Quarterly, 92(2), 404-422.

International Organization for Migration. (2008). "Migration and climate change." (Geneva, International Organization for Migration (IOM), No. 31 prepared by Oli Brown). http://www.iom.int

Lange, D. (2011). "Origin of the Yoruba and 'The lost tribes of Israel." Anthropos 106, 579-595.

Lee, E. S. (1966). “A Theory of migration.” Demography, 3(1), 47-57.

Lieberson S. (1996). Earlier Immigration to the United States: Historical Clues for Current Issues of Integration. In: Carmon N. (Eds) Immigration and Integration in Post-Industrial Societies. Migration, Minorities and Citizenship. (Palgrave Macmillan, London).

McDaniel, E. L., Nooruddin, I., and Shortle, A. F. (2011). "Divine boundaries: How religion shapes citizens' attitudes toward immigrants." American Politics Research 39(1), $205-233$

Mohammad, K. K. R. and Bali, A. O. (2017). "The Six-Day war and its impact on Arab and Israeli conflict." History Research, 7(2), 90-101

Morris, B. (2008). “1948: The first Arab-Israeli war.” (New Haven: Yale UP).

Motlhabi, M. (1987). "Black resistance to apartheid future prospects.” Journal of Black Theology in South Africa, 3-12

Musisi, J. S. (1981). "Communication with the Third World Countries.” Proceedings of the IATUL Conferences. Paper 5. http://docs.lib.purdue.edu/iatul/1981/papers/5

Naude, J. A. (1978). "Islam in Africa." Paper presented at the South African Institute of Internal Affairs. Johannesburg.

Oberman, K. (2016) "Immigration as a human right," in S. Fine and L. Ypi, eds., Migration in Political Theory: The Ethics of Movement and Membership, (Oxford: Oxford University Press), 32-56.

Pillay, S. (2004). "Where do you belong? Natives, foreigners and apartheid South Africa." African Identities 2(2), 215-232

Ringmar, E. (2016). The Muslim Caliphates. In History of International Relations Open Book Publishers.

Roberts, W. (1987). Leadership secrets of Attila the Hun. (New York: Warner Books, Inc.)

Schneider, F. (2015). "Does corruption promote emigration?" Johannes Kepler University, Austria, and IZA, Germany, doi: 10.15185/izawol.192 wol.iza.org

De Souza, P. (2008). The ancient world at war. (London: Thames \& Hudson Ltd.) 
UN News (31July 2019): Climate change (Global Perspective Human Stories) UNICEF/UNI82205/Holt Wiegand, S. (2014). U.S. History for dummies (Hoboken, NJ: John Woley \& Sons) 